\title{
PROFILE OF SPINAL CORD TRAUMA VICTIMS TREATED AT A REFERENCE UNIT IN SÃO PAULO
}

\author{
PERFIL DAS VÍTIMAS DE TRAUMA RAQUIMEDULAR ATENDIDAS EM UMA UNIDADE \\ DE REFERÊNCIA DE SÃO PAULO
}

\section{PERFIL DE LAS VÍCTIMAS DE TRAUMA RAQUIMEDULAR ATENDIDAS EN UNA UNIDAD DE REFERENCIA DE SÃO PAULO}

\begin{abstract}
Alex Oliveira de Araujo ${ }^{1}$, Danilo de Souza Ferronato ${ }^{1}$, Ivan Dias da Rocha ${ }^{1}$, Raphael Martus Marcon ${ }^{1}$, Alexandre Fogaça Cristante”,
\end{abstract} Tarcisio Eloy Pessoa de Barros Filho',

1. Universidade de São Paulo. Orthopedics and Traumatology Institute of the Hospital das Clínicas da Faculdade de Medicina, São Paulo, SP, Brazil.

\begin{abstract}
Introduction: Spinal cord trauma (SCT) is an important cause of morbidity and mortality around the world. It affects different age groups, especially young adults who are victims of high-energy trauma. The most effective way to reduce the incidence of spinal cord trauma and its consequences is through preventive campaigns and control and surveillance measures through public agencies. The objective of this study is to outline the epidemiological profile of patients with spinal cord trauma attended at a tertiary care center in the city of São Paulo. Methods: Retrospective, cross-sectional study performed at a reference center for the care of patients with spinal cord injury in the State of São Paulo. Data were collected from the medical records of patients with spinal cord trauma between 2012 and 2016. Results: Of the 515 patients with spinal trauma, $153(29.7 \%)$ had spinal cord injury of which $131(85.62 \%)$ were male, and $22(14.37 \%)$ were female, in a ratio of approximately 6:1. The mean age was 39.45 years. The main cause of spinal cord trauma observed was the fall from heights, with 72 cases (47.05\%), and $52.94 \%$ were classified as Frankel A. Conclusions: The results showed that the majority of the patients were young, economically active, with low educational level, exposed to accidents that could be largely avoided. Most of these patients also had severe disabling injuries, which usually bring considerable psychological sequelae and economic consequences to the individual and to society. Level of evidence: IV. Type of study: Case series.
\end{abstract}

Keywords: Spinal cord; Spinal injuries; Traumatic myelopathy.

\section{RESUMO}

Introdução: O traumatismo raquimedular (TRM) é uma importante causa de morbi-mortalidade ao redor mundo. Acomete diferentes faixas etárias, principalmente os adultos jovens vítimas de trauma de alta energia. A forma mais eficaz de diminuir a incidência do traumatismo raquimedular e suas consequências é através de campanhas preventivas e medidas de controle e fiscalização através dos órgãos públicos. O objetivo deste estudo é traçar o perfil epidemiológico dos pacientes vítimas de traumatismo raquimedular, atendidos em um centro de atendimento terciário da cidade de São Paulo. Métodos: Estudo retrospectivo, transversal, realizado em um centro de referência de atendimento de pacientes vítimas de traumatismo raquimedular do estado de São Paulo. Os dados foram colhidos dos prontuários dos pacientes vítimas de traumatismo raquimedular entre os anos de 2012 a 2016. Resultados: Dos 515 pacientes vítimas de traumatismo da coluna espinhal, 153 (29,7\%) apresentaram traumatismo raquimedular. 131 (85,62\%) foram do sexo masculino, 22 (14,37\%) foram pacientes do sexo feminino, em uma relação de aproximadamente 6:1. A média de idade foi de 39 a 45 anos. A principal causa de trauma raquimedular observada foi a queda de altura, com 72 casos (47,05\%). 52,94\% dos pacientes apresentaram-se em Frankel A. Conclusão: Os resultados mostraram que a maioria dos pacientes eram de jovens, economicamente ativos, com baixo nível educacional, expostos a acidentes que, em grande parte, poderiam ser evitados. A maioria destes pacientes também apresentou lesões graves, incapacitantes, que costumam trazer sequelas psíquicas e econômicas consideráveis para o indivíduo e para a sociedade. Nível de Evidência: IV. Tipo de estudo: Série de Casos.

Descritores: Medula Espinal; Traumatismos da coluna vertebral; Mielopatia.

\section{RESUMEN}

Introducción: El trauma raquimedular (TRM) es una causa importante de morbidad y mortalidad en todo el mundo. Afecta a diferentes grupos de edad, especialmente los adultos jóvenes que son víctimas de traumas de alta energía. La forma más efectiva de reducir la incidencia de traumatismos de la médula espinal y sus consecuencias es a través de campañas de prevención y medidas de control y vigilancia de agencias públicas. El objetivo de este estudio es delinear el perfil epidemiológico de los pacientes con trauma raquimedular atendidos en un centro de atención terciaria en la ciudad de São Paulo. Métodos: Estudio retrospectivo, transversal realizado en un centro de referencia para el cuidado de los pacientes con trauma raquimedular en el Estado de São Paulo. Los datos se obtuvieron de las historias clínicas de pacientes con traumatismo de la médula espinal entre 2012 y 2016. Resultados: De los 515 pacientes con trauma raquimedular, 153 (29,7\%) tenían lesiones de la médula espinal, de los cuales 131 (85,62\%) eran hombres y 22 (14,37\%) eran mujeres, en una proporción de aproximadamente 6:1. La edad media fue de 39,45 años. La principal causa de trauma raquimedular fue la caída desde la altura, con 72 casos (47,05\%), y el 52,94\% se clasificó como Frankel A. Conclusiones: Los resultados mostraron que la mayoría de los pacientes eran jóvenes, económicamente activos, con un bajo nivel educativo, expuestos a accidentes que podrían evitarse en gran medida. La mayoría de estos pacientes también tenían lesiones incapacitantes severas, que a menudo traen secuelas psicológicas importantes y consecuencias económicas para el individuo y la sociedad. Nivel de evidencia: IV. Tipo de estudio: Serie de casos.

Descriptores: Médula espinal; Traumatismos vertebrales; Mielopatía traumática. 


\section{INTRODUCTION}

Spinal cord trauma (SCT) usually leads to serious consequences for the population, whether physical, psychological, or economic, and these consequences generally persist for the rest of the victim's life. $^{1-2}$ It is a significant cause of morbidity, mortality, and disability worldwide, affecting mainly young, economically active adults. ${ }^{3-4}$

The incidence of spinal cord injury reported in the literature ranges from 12.1 to 57.8 cases per million people in developed countries and from 12.7 to 29.7 in developing countries. ${ }^{3}$ The main causes of SCT are automobile accidents, falls from heights, sports injuries, and gunshot wounds. The victims of SCT usually remain hospitalized for a relatively long period, requiring specialized multidisciplinary treatment from initial care, through treatment of their complications, to rehabilitation. The survival of these patients has increased with improvements in pre-hospital care and with the technical advancements in treatment and rehabilitation, but the incidence of new cases remains high. ${ }^{4}$

Characterization of the epidemiological profile of patients who are victims of SCT is extremely important so public agencies can develop healthcare policies targeting prevention and improved care for these patients. Knowledge of the type of trauma, the frequency, the severity, and the associated complications help in the planning of these policies. ${ }^{2,5}$

The objective of this study was to outline the epidemiological profile of patients who were victims of spinal cord trauma treated at a tertiary care center in the city of São Paulo.

\section{METHODS}

This was a retrospective, cross-sectional study conducted at the Orthopedics and Traumatology Institute of the Hospital das Clínicas da Faculdade de Medicina da Universidade de São Paulo. The data were collected from the medical records of patients who suffered spinal cord trauma and were treated at that institute between 2012 and 2016. The study was approved by the Institutional Review Board as opinion number 2.181.409 and the Informed Consent Form was not required.

The following data were collected: sex, age, education level, cause of the injury, type of neurological deficit according to the Frankel scale, level and classification of fractures according to the $\mathrm{AO}$ cervical and thoracolumbar spinal fractures classification system, in addition to the Anderson and D'Alonzo and Levine Edwards classifications for upper cervical fractures. ${ }^{6-10}$ The type of treatment performed and the number of levels involved were also analyzed. Patients who were victims of spinal injury without neurological deficit (Frankel E) and, therefore, with no spinal cord lesion, were excluded from the study.

Patient characteristics (for example, age, sex, trauma mechanism, Frankel scale) and the characteristics of the injury (level of the injury and $\mathrm{AO}$ classification) were analyzed descriptively. The continuous variables were expressed as averages with standard deviations and medians. The categorical variables were expressed as numbers of cases and percentages. The data obtained were grouped, categorized according to the study objectives, and loaded into a Microsoft Office Excel spreadsheet. The results were presented in table, figure, and chart formats. Summarized statistics were tabulated (number, method, average, standard deviation, minimum and maximum values for quantitative data and frequency counts for qualitative data).

\section{RESULTS}

Between 2012 and 2016, 515 patients, victims of spinal trauma, were treated. Of these, $153(29.7 \%)$ had spinal cord trauma presenting some level of neurological deficit at the time of initial care.

Of the 153 patients, 131 (85.62\%) were male and 22 (14.37\%) were female, for a ratio of approximately 6:1 for cases involving men versus women (Figure 1). Patient age ranged from 14 to 88 years, with an average of 39.45 years of age (standard deviation $=15.64$ ) (Figure 2).

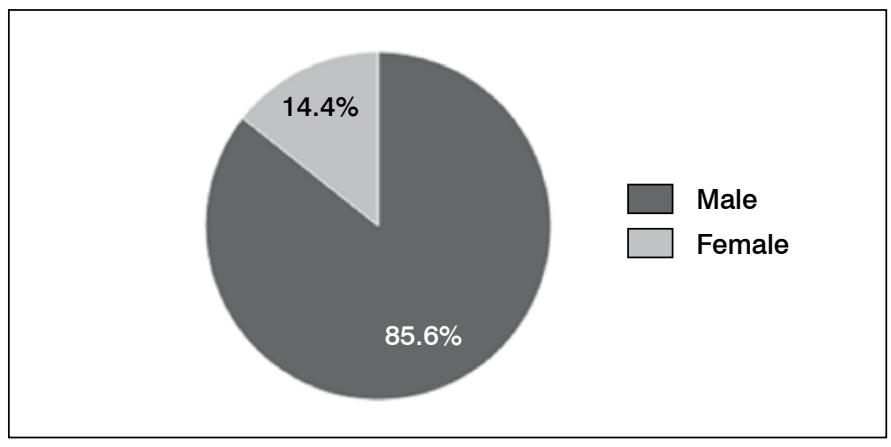

Figure 1. Distribution of SCT by sex.

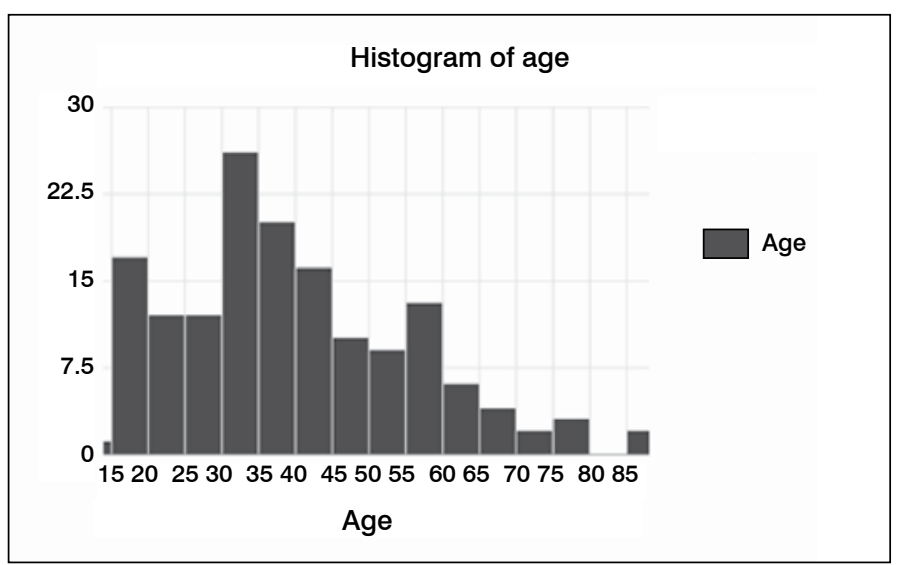

Figure 2. Distribution of patients with SCT by age.

In terms of education level, 106 (69.28\%) did not complete high school and 47 (30.72\%) graduated from high school (Figure 3).

Because it is a public health network referral center for patients suffering from spinal cord trauma, several municipalities send cases to be treated at this location. Of the 153 cases, 58 (37.90\%) were from São Paulo, 11 (7.18\%) from Barueri, 11 (7.18\%) from Osasco, 10 (6.53\%) from Carapicuíba, 8 (5.22\%) from Cotia, and 7 (4.57\%) from Itapevi, with the remaining patients from various other cities in the state of São Paulo.

The main cause of spinal cord injury observed was from falls from heights, with 72 cases (47.05\%), followed by motorcycle accidents with 27 cases (17.64\%), automobile accidents with 20 cases (13.07\%), being run over with 9 cases $(5.8 \%)$, and diving in shallow water with six cases (3.9\%). There were only four cases secondary to gunshot wounds and the remaining cases were from other causes, such as falling from a standing position, the falling of a heavy object, and physical aggression.

In terms of the level affected, there were 66 cases of lesions of the lower cervical spine (43.13\%), followed by 38 cases of thoracic spine lesions (24.83\%), 27 cases of lesions of the thoracolumbar transition (17.64\%), 17 cases of lumbar lesions (11.11\%), four cases of high cervical spine lesions (2.61\%), and 1 case of a concomitant thoracic and lumbar lesion.

The distribution of neurological deficits according to the Frankel scale was as follows: 81 cases of Frankel A (52.94\%), 38 cases of Frankel D (24.83\%), 19 cases of Frankel C (12.41\%), and 15 cases of Frankel B (9.80\%) (Figure 4).

During treatment, 70 cases had to be admitted to the ICU (45.75\%). The average number of levels involved in the surgery was four. According to AO classification for cervical, thoracic, and lumbar spine injuries, type $\mathrm{C}$ was the most common, both in the cervical (43 cases) and thoracolumbar (45 cases) groups, as can be observed in Table 1. There were four high cervical fractures, three cases of Anderson and D'Alonzo type two dens fractures and one case of Levine Edwards type I fracture of C3. 


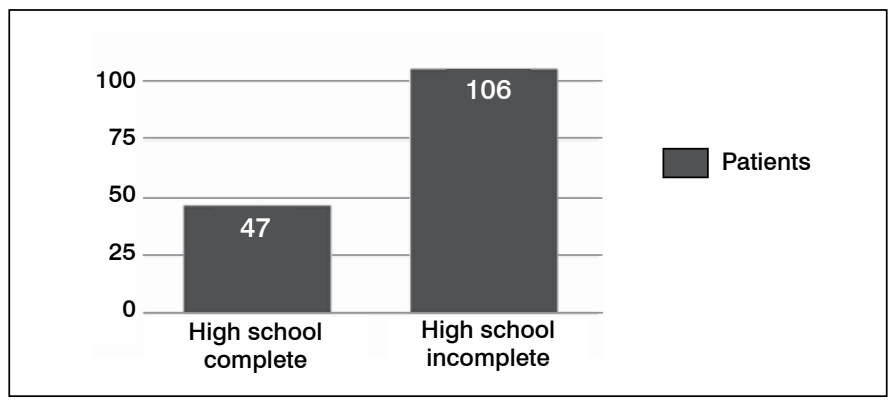

Figure 3. Distribution of SCT by Education Level.

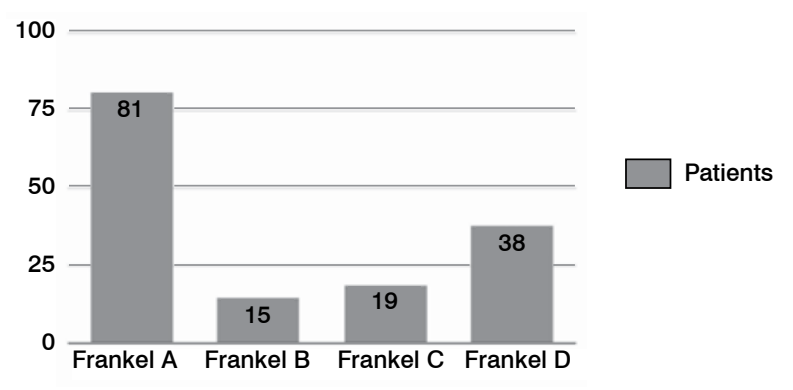

Figure 4. Distribution of SCT according to the Frankel scale.

Table 1. AO classification of low cervical and thoracolumbar fractures.

\begin{tabular}{c|c|c|c|c|c|c|c|c|c}
\hline TYPE & A0 & A1 & A2 & A3 & A4 & B1 & B2 & B3 & C \\
\hline Low cervical & 5 & 1 & 0 & 0 & 3 & 0 & 13 & 1 & 43 \\
\hline $\begin{array}{c}\text { Thoracic and/ } \\
\text { or lumbar }\end{array}$ & 0 & 0 & 2 & 6 & 15 & 2 & 11 & 2 & 45 \\
\hline
\end{tabular}

\section{DISCUSSION}

The average age of the spinal cord trauma patients was 39.45 years, a bit lower than the averages usually observed in developed countries. In a study conducted in Ontario, the average age observed was 51.3 years (standard deviation 20.1 years). ${ }^{11}$ In Japan, S Katoh et al. reported the average age of victims of spinal cord trauma in Tokushima as $67.6 \pm 14.6$ years. ${ }^{12}$ This result reflects the Brazilian age pyramid, which, although in the process of aging, still has a greater proportion of young people as compared to developed countries.
Most of the patients were male (85.62\% were male and $14.37 \%$ were female), which agrees with the global literature. This is probably due to the greater exposure of men to high-impact traumas, whether on the job or related to sports or violence.

The main cause of spinal cord injury encountered in this study was falls from heights (ladders, scaffolding, slabs, embankments, floors of buildings), responsible for $47.05 \%$ of the injuries, well ahead of motorcycle and automobile accidents $17.64 \%$ and $13.07 \%$, respectively. In North America, the main cause of spinal cord injury is accidents associated with motor vehicle use. In a study conducted in Ontario, Canada, CM Couris et al. observed that the main cause was falls in middle-aged men. ${ }^{11}$ A study conducted in South Africa showed that in Cape Town the main cause of spinal cord injury was armed assault, with injuries caused by firearms or knives. ${ }^{13}$

The education level of the patients is directly related to the incidence of spinal cord injury. Most of the patients did not complete high school (69.28\%), which suggests that education level is inversely proportional to exposure to accidents that can lead to spinal cord injury. This is a reality in underdeveloped or developing countries that have a low human development index with a low population education level and higher exposure to accidents and violence.

The cervical spine was the most affected level, at $43.13 \%$, followed by injuries of the thoracic spine with $24.83 \%$ and of the thoracolumbar transition with $17.64 \%$. According to the literature, the cervical spine is usually the most affected location, whether with or without associated bone lesions. ${ }^{13}$ We observed that most of the patients arrived at the emergency room with full deficit (52.94\% of the victims classified as Frankel A) and in most of the more serious injuries, with dislocation or facet joint subluxation (54.24\% of the injuries were classified as $\mathrm{AO}$ type $\mathrm{C}$ ).

\section{CONCLUSION}

These data help to show a bit of the impact that spinal cord trauma has on the population of the state of São Paulo. We observed that most of the patients were young, economically active, with a low education level, and exposed to accidents that for the most part could be prevented. Most of these patients also had serious disabling injuries, which often lead to significant psychological sequelae and economic consequences for the individual and for society.

All authors declare no potential conflict of interest related to this article.

CONTRIBUTION OF THE AUTHORS: Each author made significant individual contributions to this manuscript. AOA (0000-0002-3245-6155)* and DSF $(000-0002-6823-3308)^{\star}$ were the main contributors to the preparation of the manuscript. IDR $(0000-0001-6533-4528)^{\star}, \mathrm{RMN}(0000-0001-5958-5646)^{\star}$, and AFC (0000-0002-7797-5274)* performed the surgeries. AOA and DSF collected the clinical data. AFC and IDR evaluated the statistical analysis data. TEPBF $(0000.000 .27969-7845)^{\star}$, RMN, AOA, and DSF conducted the bibliographical research, reviewed the manuscript, and contributed to the intellectual concept of the study. ${ }^{*}$ ORCID (Open Researcher and Contributor ID).

\section{REFERENCES}

1. Chen $Y, \mathrm{HeY}$, DeVivo MJ. Changing Demographics and Injury Profile of New Traumatic Spinal Cord Injuries in the United States, 1972-2014.Arch Phys Med Rehabil. 2016;97(10):1610-9.

2. Burke DA, Linden RD, Zhang YP, Maiste AC, Shields CB. Incidence Rates and Populations at Risk for Spinal Cord Injury: A Regional Study. Spinal Cord 2001;39(5):274-8.

3. Pérez K, Novoa AM, Santamariña-Rubio E, Narvaez Y, Arrufat V, Borrell C et al. Incidence Trends of Traumatic Spinal Cord Injury and Traumatic Brain Injury in Spain, 2000-2009. Accid Anal Prev. 2012;46:37-44.

4. O'Connor P. Incidence and Patterns of Spinal Cord Injury in Australia. Accid Anal Prev. 2002;34(4):405-15.

5. Grossman RG, Frankowski RF, Burau KD, Toups EG, Crommett JW, Johnson MM, et al. Incidence and Severity of Acute Complications after Spinal Cord Injury. J Neurosurg Spine. 2012;17(1 Suppl):119-28.

6. Levine AM, Edwards CC. The Management of Traumatic Spondylolisthesis of the Axis. J Bone Joint Surg Am. 1985;67(2):217-26.

7. Frankel HL, Hancock DO, Hyslop G, Melzak J, Michaelis LS, Ungar GH et al. TheValue of Postural Reduction in the Initial Management of Closed Injuries of the Spine with Paraplegia and Tetraplegia. I. Paraplegia. 1969;7(3):179-92.
8. Vaccaro AR, Oner C, Kepler CK, Dvorak M, Schnake K, Bellabarba C, et al. AOSpine Thoracolumbar Spine Injury Classification System: Fracture Description, Neurological Status, and Key Modifiers.Spine (PhilaPa 1976). 2013;38(23):2028-37.

9. Vaccaro AR, Koerner JD, Radcliff KE, Oner FC, Reinhold M, Schnake KJ, et al. AOSpine Subaxial Cervical Spine Injury Classification System. Eur Spine J. 2016;25(7):2173-84.

10. Anderson LD, D'Alonzo RT. Fractures of the Odontoid Process of the Axis. $J$ Bone Joint Surg Am. 1974:56(8):1663-74.

11. Couris CM, Guilcher SJ, Munce SE, Fung K, Craven BC, Verrier M. Characteristics of Adults with Incident Traumatic Spinal Cord Injury in Ontario, Canada. Spinal Cord. 2010;48(1):39-44.

12. Katoh S, Enishi T, Sato N, Sairyo K. High Incidence of Acute Traumatic Spinal Cord Injury in a Rural Population in Japan in 2011 and 2012: An Epidemiological Study. Spinal Cord. 2014;52(4):264-7.

13. Joseph C, Delcarme A, Vlok I, Wahman K, Phillips J, Nilsson Wikmar L. Incidence and Aetiology of Traumatic Spinal Cord Injury in Cape Town, South Africa: A Prospective, Population-Based Study. Spinal Cord. 2015;53(9):692-6. 